$N^{\circ} 2005-16$

October

China and the Relationship between the Oil Price and the Dollar

Agnès Bénassy-Quéré, Valérie Mignon \& Alexis Penot 


\section{China and the Relationship between the Oil Price and the Dollar}

Agnès Bénassy-Quéré

Valérie Mignon

Alexis Penot

No $2005-16$ October 


\section{Contents}

\begin{tabular}{llr}
\hline 1 & Introduction & 8
\end{tabular}

2 Oil and dollar: an empirical investigation $\quad 11$

2.1 First glance at the data $\ldots \ldots \ldots \ldots \ldots \ldots$

2.2 Cointegration . . . . . . . . . . . . . . . . . . . 11

2.3 Causality . . . . . . . . . . . . . . . . . . . . . . . . 14

2.4 Robustness . . . . . . . . . . . . . . . . . . . . . . 15

\begin{tabular}{lll}
\hline Oil and dollar: what is new with China? & 17
\end{tabular}

3.1 The model . . . . . . . . . . . . . . . . . . . . . . . . 17

3.2 The impact of the oil price on the euro/dollar exchange rate . . . . . . . . 20

3.3 The impact of the euro/dollar exchange rate on the oil price . . . . . . . . 22

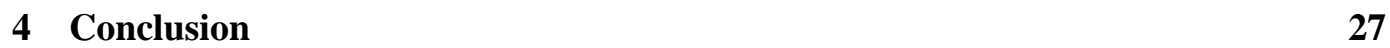

\begin{tabular}{lll}
\hline 5 & References & 28
\end{tabular}

\begin{tabular}{|ll}
\hline A Unit root tests & 30
\end{tabular}

B The long-term impact of the oil price on the dollar 30 
CEPII, Working Paper No 2005-16.

\section{China and the Relationship between the Oil Price and the Dollar}

\section{SUMMARY}

All over the world, oil is denominated in US dollar. Indeed, the price in euro or in yen is seldom commented on. Still, this is the relevant price for all importing countries not running a fixed exchange rate against the US dollar. Europe for instance did not benefit from the decrease in oil prices of the early 1980's because of the rise in the dollar exchange rate, but when the dollar depreciated over the 2002-2004 period, it contributed to cushion the strong increase in oil prices. Therefore, the fact that oil prices are denominated in USD raises the question of the co-movements between oil prices and the dollar exchange rate. The existing empirical research in this area generally finds a positive relationship between the two variables, i.e. a rise in the oil price coincides with a dollar appreciation on average. From this perspective, the 2002-2004 period, with a depreciating dollar when oil prices were rising, does not fit the long-run relationship.

This paper tries to revisit the relationship between oil price and USD exchange rate. We first provide evidence of a long-term relation (i.e. a cointegration relation) between the two series in real terms and of a causality running from oil to the dollar, over the 1974-2004 period. Our estimation suggests that a $10 \%$ rise in the oil price leads to a $4.3 \%$ appreciation of the dollar in real effective terms in the long run. The estimation of an error correction model shows a slow adjustment speed of the dollar real effective exchange rate to its longterm target (with a half life of deviations of about $61 / 2$ years). Although consistent with previous studies, our results are unable to explain the 2002-2004 period with a rising oil price and a depreciating dollar.

The paper then develops a theoretical model to study whether this recent period could be the beginning of a new regime stemming from the emergence of China as a large player on both oil and foreign exchange markets. Our analysis is based on an extension of Krugman (1980) to the case of four countries (the United States, the Eurozone, OPEC and China) and only one exchange rate (the dollar against the euro). The paper finds that the emergence of China reinforces the case for a depreciation of the euro in the short run following a rise in the oil price. This is due to the fall in the Chinese demand for euros stemming from the drop in the Chinese trade account. In the long run, a rise in the oil price is likely to raise the Chinese trade account due to the relatively high share of China in OPEC imports. To the extent that there is some diversification of Chinese official reserves, an oil price increase could lead to an appreciation of the euro.

The paper also shows that the emergence of China could give rise to a negative causality from the dollar to the oil price: due to the Chinese peg on the dollar, a dollar depreciation tends to boost Chinese growth due to higher exports and to money creation via official reserve accumulation. Because it is energy-intensive, this growth raises the world demand for oil, hence the oil price.

Although de jure the Chinese exchange-rate regime moved from a peg to a managed floating 
regime in July 2005, de facto the yuan has remained pegged on the dollar, which raises the case for a dollar depreciation causing a rise in the oil price. Indeed, the evolution of the dollar and of oil prices over 2002-2004 are consistent with this causality: the dollar depreciation may have reinforced oil-price hikes through Chinese exchange-rate regime and export-driven growth.

\begin{abstract}
We study cointegration and causality between the real price of oil and the real price of the dollar over the 1974-2004 period. Our results suggest that a 10\% rise in the oil price coincides with a $4.3 \%$ appreciation of the dollar in the long run, and that the causality runs from oil to the dollar. Through the development of a theoretical model, we then investigate possible reasons why this relationship could be reversed in the future due to the emergence of China as a major player on both the oil and the foreign exchange markets.
\end{abstract}

JEL classification: C22, F31, Q43.

Keywords: oil price, real exchange rate, dollar, euro, China, cointegration, causality, error correction model. 
CEPII, Working Paper No 2005-16.

\section{LA ChIne ET LE LIEN ENTRE PRIX DU PÉTROLE ET DOLlaR}

\section{RÉSUMÉ}

Partout dans le monde, le prix du pétrole s'exprime en dollars des Etats-Unis : le prix en euros ou en yens est rarement commenté. Pourtant seul le prix en monnaie nationale est pertinent pour toutes les économies dont la monnaie n'est pas fixe par rapport au dollar. L'Europe, par exemple, n'a pas profité de la baisse du prix du pétrole de la première moitié des années 80 en raison de la forte hausse du dollar ; mais lorsque le dollar s'est déprécié sur la période 2002-2004, ceci a contribué à amortir la flambée des prix du pétrole. Par conséquent, le libellé des prix du pétrole en dollars soulève la question des évolutions comparées des prix du pétrole et du taux de change du dollar.

La recherche empirique sur se sujet conclut généralement à une relation positive entre les deux variables : une hausse du prix du pétrole est en moyenne associée à une appréciation du dollar. Cependant, la période 2002-2004, avec un dollar à la baisse et un pétrole à la hausse, n'obéit pas à cette relation.

Le présent article tente de réexaminer la relation entre pétrole et dollar. Nous mettons d'abord en évidence une relation de long terme (cointégration) entre les deux séries en termes réels et une causalité allant du pétrole vers le dollar sur la période 1974-2004. L'estimation suggère qu'une hausse de $10 \%$ du prix du pétrole est associée à une appréciation du dollar en termes réels de 4,3\% à long terme. L'estimation d'un modèle à correction d'erreurs révèle que la vitesse d'ajustement du taux de change effectif réel à sa cible de long terme est lente (avec une demi-vie des écarts à la cible de long terme d'environ six ans et demi). Même si elles confirment le résultat d'études antérieures, ces conclusions ne rendent pas compte des évolutions observées en 2003 et 2004, où la hausse des prix du pétrole s'est accompagnée d'une dépréciation du dollar.

Nous présentons alors un modèle théorique pour étudier si cette période récente pourrait marquer le début d'un nouveau régime dû à l'émergence de la Chine comme acteur majeur à la fois sur le marché du pétrole et sur le marché des changes. L'analyse repose sur une extension du modèle de Krugman (1980) à quatre pays (États-Unis, Zone euro, OPEP et Chine) avec un seul taux de change (le dollar contre l'euro). On montre que l'émergence de la Chine accentue les pressions à la baisse sur l'euro à court terme en cas de hausse des prix du pétrole car la demande chinoise pour les actifs en euros diminue à la suite de la détérioration du solde extérieur chinois. A long terme, une hausse du prix du pétrole a au contraire un effet positif sur le solde extérieur chinois en raison de la part relativement importante de la Chine dans les importations de l'OPEP. Sous réserve que les autorités chinoises diversifient les réserves officielles en devises, une hausse des prix du pétrole pourrait donc conduire à une appréciation de l'euro.

Nous montrons aussi que l'émergence de la Chine pourrait donner naissance à une causalité négative du dollar vers le prix du pétrole: la monnaie chinoise étant ancrée sur le dollar, une dépréciation du dollar tend à accélérer la croissance chinoise à travers les exportations, mais 
aussi à travers le mécanisme de création monétaire via les interventions de change. Cette croissance étant intensive en énergie, la demande mondiale de pétrole augmente, ce qui fait augmenter le prix du pétrole.

La modification du régime de change intervenue en juillet 2005, avec un passage à un régime de flottement administré, n'a rien changé puisque le yuan est resté fixe de facto par rapport au dollar. L'évolution observée du prix du pétrole et du dollar en 2002-2004 pourrait bien refléter ce nouveau type d'enchaînement, la dépréciation du dollar ayant favorisé la hausse du prix du pétrole via le régime de change et le mode de croissance chinois.

\section{RÉSUMÉ COURT}

Nous étudions les relations de cointégration et de causalité entre le prix réel du pétrole et le prix réel du dollar sur la période 1974-2004. Nos résultats suggèrent qu'une hausse de $10 \%$ du prix du pétrole coïncide avec une appréciation du dollar de 4,3\% à long terme et que la causalité va du pétrole vers le dollar. À l'aide d'un modèle théorique, nous étudions ensuite comment cette relation pourrait s'inverser dans le futur en raison de l'émergence de

la Chine comme un acteur important à la fois sur le marché pétrolier et sur le marché des changes.

Classification JEL : C22, F31, Q43.

Mots Clefs : prix du pétrole, taux de change réel, dollar, euro, Chine, cointégration, causalité, modèle à correction d'erreur. 


\title{
China AND THE RELATIONSHip BETWEEN THE OIL PRICE AND THE DOLlar
}

\author{
Agnès BÉNASSY-QUÉRÉ ${ }^{1}$ \\ Valérie MIGNON2 \\ Alexis PENOT
}

\section{Introduction}

Because oil is denominated in dollars, oil-price fluctuations in domestic currency may be quite different depending on the exchange-rate regime. For instance, the 2002-2004 rise in oil prices was partly cushioned in the Eurozone by a sharp appreciation of the euro: from December 2001 to November 2004, the oil price rose by $127 \%$ in dollars, but the dollar depreciated by $44 \%$ against the euro. Hence the rise in the oil price was 'only' $83 \%$ in euro. In the same way, the dollar depreciated in 1979 when the price of oil rose sharply. From 1980 to 1985, however, Europe did not benefit from the decline in oil prices because the dollar appreciated at the same time. The evolution of the real price of oil for the United States and for the Eurozone is compared in Figure 1 |

Therefore, the fact that oil imports are denominated in US dollars raises the question of the co-movements between oil prices and the dollar exchange rate. This is indeed a crucial question for all countries not running fixed exchange rate pegs on the US dollar.

Existing empirical research on the link between oil price and dollar generally finds a positive relationship between both variables, i.e. a rise in the oil price coincides with an appreciation of the dollar (see Throop, 1993; Zhou, 1995; Dibooglu, 1996; Amano and van Norden, 1998). According to Amano and van Norden (1998), the causality runs from oilprice variations to exchange-rate changes in Germany, Japan and the United States. One theoretical challenge is then to figure out whether the recent reversal of the relationship between the oil price and the dollar could be permanent or not.

Theoretical interpretations of the link between oil prices and exchange rates have followed two main avenues. The first one focuses on oil as a major determinant of the terms of trade. Accordingly, Amano and van Norden (1998) propose a very simple model with two sectors for tradable and non-tradable goods respectively. Each sector uses both a tradable input (oil)

\footnotetext{
${ }^{1}$ CEPII. Email: agnes.benassy@ cepii.fr.

${ }^{2}$ University of Paris 10, THEMA-CNRS, and CEPII. Email: Valerie.Mignon@u-paris10.fr.

${ }^{3}$ Alexis Penot was an economist at CEPII when working on this paper. We are grateful to Virginie Coudert for helpful comments. All errors remain ours.

${ }^{4}$ The oil price in domestic currency is deflated by the domestic consumer price index.
} 
Figure 1: Real price of oil for the United States and for the Eurozone $(100=1990: 01)$

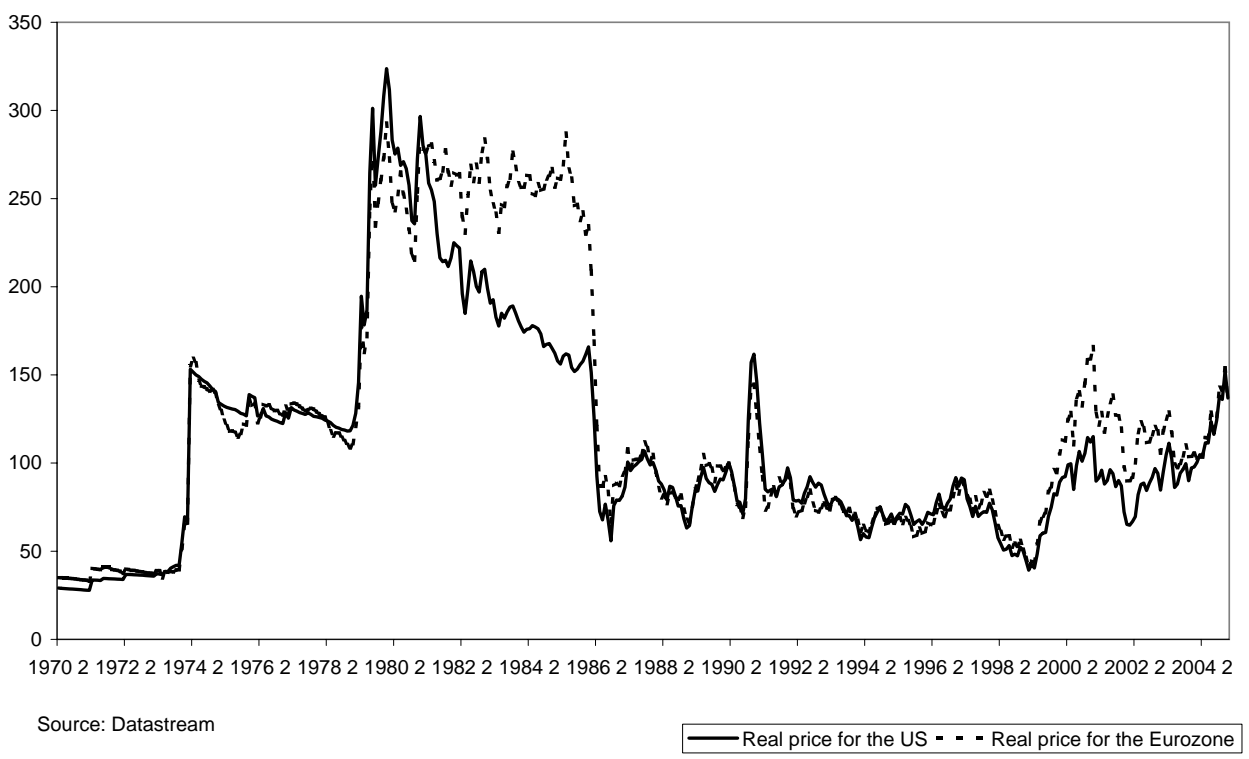

and a non-tradable one (labor). The output price of the tradable sector is fixed internationally, hence the real exchange rate is identified to the output price in the non-tradable sector. A rise in the oil price leads to a decrease in the labor price in order to meet the competitiveness requirement of the tradable sector. If the non-tradable sector is more energy-intensive than the tradable one, its output price rises and so does the real exchange rate. The opposite applies if the non-tradable sector is less energy-intensive than the tradable one. The problem with this approach is the small-economy assumption. It neglects the fact that tradable prices can rise worldwide following an oil-price shock. Allowing for this possibility (while keeping the law of one price in the tradable sector) would lead to conclude that the real exchange rate variation following an oil price shock will depend on the oil intensity of both tradable and non-tradable sectors in all the countries under review.

A second strand of the literature (Krugman, 1980; Golub, 1983) focuses on the balance of payments, hence on the tradable sector and international portfolio choices. A rise in oil prices is viewed as a wealth transfer from oil-importing countries to oil-exporting ones. 
The impact on exchange rates then depends on the distribution of oil imports across oilimporting countries and on portfolio preferences of both oil-importing countries (whose wealth declines) and oil-exporting ones (whose wealth increases). Krugman adds some dynamics in the model by assuming that OPEC will progressively use their accumulated wealth to import more goods from industrial countries. Hence in the long run the real exchange rate will depend on the geographic distribution of OPEC imports, but no longer on OPEC portfolio choices. Assuming that oil-exporting countries have a strong preference for dollar-denominated assets but not for US goods, an oil price hike will lead the dollar to appreciate in the short run but not in the long run.

This second strand of the literature is based on a three-country (the United States, Europe, OPEC), two-currency (dollar, Deutschemark or euro) framework. Such specification is justified by oil-exporting countries having a fixed exchange rate against the dollar. The introduction by Golub (1983) of a fourth country (the United Kingdom) and a third currency (the Sterling) does not change the qualitative conclusions.

In this paper, we argue that one major development in both oil market and in the international monetary system since the late 1990s has been the emergence of China as a large player. Indeed, China accounted for one fourth of world incremental oil demand over 19952004 and one third in 2004 5 Looking forward, China is expected to account for $12 \%$ of world oil demand in 2025 (instead of 7\% in 2005), whereas Western Europe is expected to fall back from $19 \%$ in 2005 to $15 \%$ in 20256

Since the late 1990s, China has also become the second largest country (after Japan) concerning official reserves in foreign currencies.7 Like OPEC, China de facto runs a fixed exchange rate against the dollar, although it claims it moved to a managed floating regime against a basket of currencies in July 2005. Furthermore, the People's Bank of China still denotes a strong preference for dollar-denominated assets. But unlike OPEC, China is an oil-importing country. We believe that this symmetry between China and OPEC could impact on the relationship between the price of oil and that of the dollar, and that this could be especially relevant since a number of large emerging countries tend to follow similar exchange-rate strategies as China. 8

First, we update the empirical assessment on the relationship between the price of oil and that of the dollar, on the basis of cointegration and causality tests over the 1974-2004 period. Then, we extend Krugman's (1980) model to include China, in order to analyze the impact of a variation in the oil price. We also investigate a possible reversal of the causality, from the exchange rate to the oil price.

The paper is organized as follows. The relationship between oil and dollar prices over 1974-

\footnotetext{
${ }^{5}$ Sources: OECD (2004) and World Bank (2005).

${ }^{6}$ Source: OPEC (2004); consistently, IMF (2005a) expects China to reach $12 \%$ of world demand in 2020 and $13.5 \%$ by 2030 .

${ }^{7}$ Source: IMF (2005b).

${ }^{8}$ This is for instance the case for India and Brazil.
} 
2004 is studied in Section 2, through both cointegration analysis and Granger-causality tests. Section 3 presents a theoretical, four-country, two-currency model where the eurodollar exchange rate reacts to the oil price depending on portfolio preferences, trade elasticities and the geographic distribution of trade. This model is an extension of Krugman (1980) in two ways. First, a fourth country (China) is introduced; second, the impact of the exchange rate on the oil price is also envisaged. Section 4 concludes.

\section{Oil and dollar: an empirical investigation}

We use monthly data of oil price and dollar exchange rate from January 1974 to November 2004 from the Datastream database. The oil price variable 9 is expressed in real terms, i.e. it is deflated by the US consumer price index. The exchange rate is the dollar real effective exchange rate $\sqrt{10}$ We also use the real exchange rate against the euro, but this rate can only be calculated from 1978:12 due to a lack of consumer price index for the Eurozone before 1978:12. Hence this second exchange rate is mainly used for robustness checks.

\subsection{First glance at the data}

Figure 2 compares the evolution of the dollar real exchange rates both against the euro (LRER) and in effective terms (LREER), with the real oil price (LOIL) over 1974:012004:11, in logarithms. Three observations can be made. First, the oil price is more volatile than both exchange rates; not surprisingly, the dollar is more stable in effective terms than against the euro. Second, the dollar and the oil price seem to move quite in parallel except in the 1980-1985 period, when the oil price decreased from its 1979 peak while the dollar was appreciating sharply, and in 2002-2004 where the reverse pattern was observed. Third, the oil price seems to "lead" the exchange rate variable. In other words, if a causality between the two variables exists, it seems to go from the oil price to the exchange rate.

We try to check these visual impressions through econometric analysis. The first mandatory step is to study the order of integration of both variables. The results of the AugmentedDickey-Fuller (ADF) and Phillips-Perron (PP) tests are reported in Table A1 in the Appendix. It turns out that both series are integrated of order one.

\subsection{Cointegration}

Here we investigate the existence of a long-run relationship between the real oil price (LOIL) and the real effective exchange rate of the dollar (LREER) over 1974:01-2004:11.

\footnotetext{
${ }^{9}$ Market price crude petroleum.

${ }^{10}$ An increase indicates an appreciation of the dollar. The construction of this variable is detailed in OECD's Main Economic Indicators.
} 
Figure 2: Real exchange rate of the dollar and real oil price, in logarithm $(\log (100)=1990: 01)$

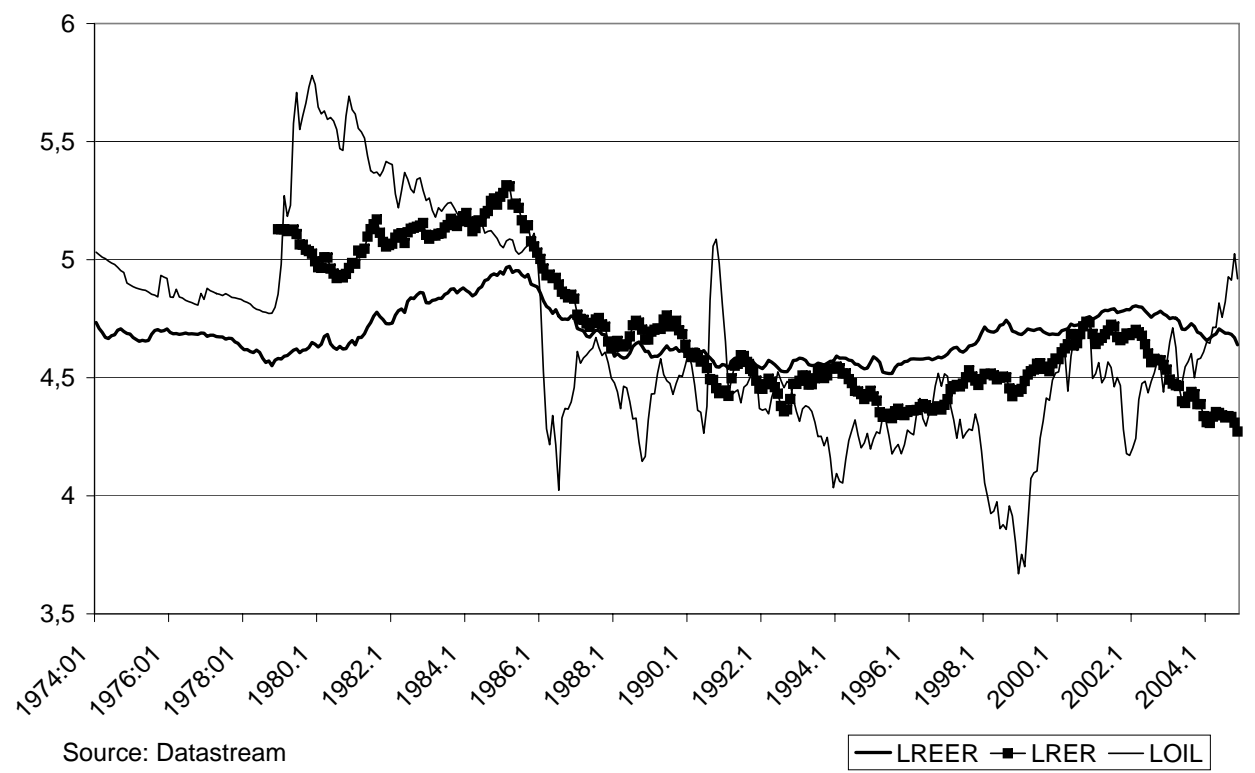

To this aim, we carry out the trace test proposed by Johansen (1988) and Johansen and Juselius (1990). The results are reported in Table 1 .

According to the trace test, the null hypothesis of no cointegration between the two variables is rejected at the 5\% significance level. Therefore, there is a long-term equilibrium relationship between the oil price and the dollar effective exchange rate. The estimation of this long-term relationship (reported in Table 11) shows that an increase in oil price by $10 \%$ results, other things equal, in a dollar appreciation by around $4.3 \%$.

The cointegration between the two variables allows to estimate a vector error correction model (VECM) in order to describe the dynamic adjustment of the variables to long-run equilibrium. The VECM estimation is reported in Table 2 .

The results show that the error correction term has a negative and significant impact on exchange-rate log-variations. Therefore, there is a mean-reverting process of the exchange rate to its long-term target. However, the adjustment speed is very low $(-0.0088)$, meaning 
Table 1: Cointegration test

\begin{tabular}{ccc}
\hline Null hypothesis & Trace statistic & p-value \\
\hline No relation & $15.98^{*}$ & 0.04 \\
\hline$L R E E R_{t}=2.6593+0.4332 L O I L_{t}$ \\
\hline *: rejection of the null hypothesis at the $5 \%$ significance level.
\end{tabular}

Table 2: Error correction model estimation

\begin{tabular}{ccc}
\hline & $\Delta$ LREER & $\Delta$ LOIL \\
\hline$z_{t-1}$ & -0.008874 & 0.054404 \\
& {$[-2.25075]$} & {$[2.15787]$} \\
$\Delta$ LREER $_{t-1}$ & 0.265092 & -0.292383 \\
& {$[5.07313]$} & {$[-0.87501]$} \\
$\Delta$ LREER $_{t-2}$ & -0.020041 & 0.699690 \\
& {$[-0.38501]$} & {$[2.10206]$} \\
$\Delta$ LOIL $_{t-1}$ & -0.007210 & 0.203523 \\
& {$[-0.88532]$} & {$[3.90787]$} \\
$\Delta$ LOIL $_{t-2}$ & -0.007081 & 0.002152 \\
& {$[-0.87187]$} & {$[0.04144]$} \\
Constant & -0.000152 & 0.001464 \\
& {$[-0.21515]$} & {$[0.32494]$} \\
LB $(4)=0.1898$ & $;$ LB $(8)=0.7875 ;$ LB $(12)=0.1847$ \\
\multicolumn{3}{c}{ residuals } \\
\hline
\end{tabular}

$z_{t-1}$ : residuals of the long-term relationship between LREER and LOIL in t-1. Between brackets: $\mathrm{t}$-statistics of estimated coefficients. $\mathrm{LB}(\mathrm{k})$ is the p-value of the Ljung-Box test of no autocorrelation for k lags. 
that only $10 \%$ of the adjustment to equilibrium is achieved each year ${ }^{11}$ This corresponds to a half-life of deviation of about $61 / 2$ years, which is quite long $\left.\right|^{12}$ Note that the errorcorrection term is positive in the oil price equation, meaning that there is no mean-reverting process for the oil price towards its long-term equilibrium value. In the next sub-section, the oil price is shown to be exogenous.

\subsection{Causality}

The existence of a cointegration relationship between the two variables means that at least one of them Granger-causes the other. It is consequently relevant to study the direction of the causality and the nature (exogenous or not) of the considered variables.

We proceed in two steps. First, we test the existence of a long-term causality between the two variables with exogeneity tests. By doing so, we try to determine whether the exchange rate and/or oil price are weakly exogenous according to Engle, Hendry and Richard (1983). This entails testing whether the long-term relationship, captured by the residual of the cointegration relationship, is significant or not in the autoregressive equations of exchange rate $\log$-variations and oil price log-variations. The results of the likelihood ratio test reported in Table 3 show that the oil price is weakly exogenous while the exchange rate is not. In other words, the deviation from the long-term target significantly influences the exchange rate but does not affect oil prices.

Table 3: Results of the exogeneity tests (p-values)

\begin{tabular}{cc}
\hline Variable & p-value \\
\hline Exchange rate & 0.0245 \\
Oil price & 0.7756 \\
\hline
\end{tabular}

In a second step, we study Granger causality. To this end, we estimate a VAR model in level and we apply Granger causality tests. The results are reported in Table 4 for different lags, $p$, in the VAR process.

The null hypothesis is no causality. Table 4 clearly shows that the exchange rate does not cause the oil price. It means that even though oil is denominated in dollars, dollar variations have no significant effect on oil prices. Conversely, a causality can be observed from the

\footnotetext{
${ }^{11}$ Remember that 0.0088 holds for the monthly frequency of our data and that it equals around $10 \%$ on an annual basis.

${ }^{12}$ The studies on purchasing power parity usually find a half-life between three and five years (Rogoff, 1996).
} 
China and the Relationship between the Oil Price and the Dollar

Table 4: Results of causality tests (p-values)

\begin{tabular}{lcccccccc}
\hline & VAR(1) & VAR(2) & VAR(3) & VAR(4) & VAR(6) & VAR(8) & VAR(10) & VAR(12) \\
\hline $\mathrm{O} \rightarrow \mathrm{C}$ & $0.0529 *$ & 0.1300 & 0.1800 & 0.1124 & 0.2035 & 0.2525 & 0.4485 & 0.4069 \\
$\mathrm{C} \rightarrow \mathrm{O}$ & 0.8473 & 0.9600 & 0.1704 & 0.2591 & 0.4653 & 0.5722 & 0.7687 & 0.1193 \\
\hline $\mathrm{O} \rightarrow \mathrm{C}$ is for the null hypothesis of no causality from oil prices to the exchange rate. \\
$\mathrm{C} \rightarrow \mathrm{O}$ is for the null hypothesis of no causality from the exchange rate to oil prices. \\
$*:$ rejection of the null hypothesis at the $10 \%$ significance level.
\end{tabular}

oil price to the dollar, at the $10 \%$ level, in the model with one lag. On the whole, the conclusions obtained with the exogeneity tests are confirmed.

\subsection{Robustness}

As shown in Figure 2, the real exchange rate of the dollar is more volatile against the euro than in effective terms. As a robustness check, we perform the same analysis as above on the bilateral rate against the euro, over 1980:01-2004:11. For the sake of comparability, we also re-estimate the same relations on the real effective exchange rate over the same subperiod. Finally, this robustness exercise also allows us to check for the sensitivity of the results to the sample period. The results of the ADF and PP tests are reported in Table $\mathrm{A} 2$ in the Appendix. They indicate that both exchange rate series are integrated of order one on this sub-period, and so is the real price of oil. We now turn to the cointegration analysis.

Table 5: Cointegration test on the 1980.01-2004.11 period

\begin{tabular}{ccc}
\hline \hline Null hypothesis & Trace statistic & p-value \\
\hline \multicolumn{3}{c}{ Real effective exchange rate } \\
No relation & $14.93^{*}$ & 0.06 \\
$L R E E R_{t}=2.7229+0.4258 L O I L_{t}$ \\
\hline \multicolumn{3}{c}{ Real bilateral exchange rate } \\
No relation $\quad 13.84^{*}$ & 0.08 \\
$L R E R_{t}=$ & $0.3222+0.9446 L O I L_{t}$ \\
\hline *: rejection of the null hypothesis at the $10 \%$ significance level.
\end{tabular}

According to the trace test (Table 5), the null hypothesis of no cointegration between the exchange rate and the oil price is rejected at the $10 \%$ significance level for both exchange 
rate series. The estimation of the long-term relationship (reported in Table 5) shows that it is positive and that the elasticity of the exchange rate to oil prices is larger for the bilateral series (LRER) than for the effective one (LREER). Globally, it appears that our results are robust both to the nature - effective or bilateral - of the exchange rate series and to the considered period.

The VECM estimation is reported in Table 6. It shows the error correction term to be a significant driving force for exchange-rate variations. Concerning the effective exchange rate, the adjustment speed remains low even if it is higher than for the whole period: it is equal to -0.0109 , which means that $12.3 \%$ of the adjustment to the equilibrium is made every year, for a half-life of 5 years and 3 months. A similar result is obtained with the bilateral exchange rate since the adjustment speed is equal to -0.0094 . Thus, these estimations are in accordance with those obtained on the whole period.

Table 6: Error correction model estimation

\begin{tabular}{|c|c|c|c|c|}
\hline & \multicolumn{2}{|c|}{ Effective exchange rate } & \multicolumn{2}{|c|}{ Bilateral exchange rate } \\
\hline & $\triangle \mathrm{LREER}$ & $\Delta$ LOIL & $\triangle \mathrm{LRER}$ & $\Delta$ LOIL \\
\hline \multirow{2}{*}{$z_{t-1}$} & -0.010964 & 0.066742 & -0.009393 & 0.046328 \\
\hline & {$[-2.29808]$} & [ 2.59961] & {$[-1.83894]$} & [ 2.92144] \\
\hline \multirow[t]{2}{*}{$\Delta \mathrm{LCH}_{t-1}$} & 0.281822 & -0.226199 & 0.348689 & -0.148813 \\
\hline & [ 4.83666] & {$[-0.72142]$} & {$[5.98282]$} & {$[-0.82241]$} \\
\hline \multirow[t]{2}{*}{$\Delta \mathrm{LCH}_{t-2}$} & -0.036572 & 0.363561 & -0.119798 & 0.233324 \\
\hline & {$[-0.62909]$} & {$[1.16218]$} & {$[-1.95250]$} & [ 1.22486$]$ \\
\hline \multirow[t]{2}{*}{$\Delta \mathrm{LOIL}_{t-1}$} & 0.004947 & 0.314950 & -0.003353 & 0.328769 \\
\hline & {$[0.46123]$} & {$[5.45719]$} & {$[-0.17805]$} & {$[5.62360]$} \\
\hline \multirow[t]{2}{*}{$\Delta \mathrm{LOIL}_{t-2}$} & -0.011688 & -0.099611 & -0.020414 & -0.104962 \\
\hline & {$[-1.08215]$} & {$[-1.71392]$} & {$[-1.04114]$} & {$[-1.72422]$} \\
\hline \multirow[t]{2}{*}{ Constant } & $-3.93 \mathrm{E}-05$ & -0.002283 & -0.001839 & -0.001529 \\
\hline & {$[-0.04797]$} & {$[-0.51850]$} & {$[-1.28922]$} & {$[-0.34538]$} \\
\hline \multicolumn{3}{|c|}{ Tests on residuals } & \multicolumn{2}{|c|}{ Tests on residuals } \\
\hline \multicolumn{3}{|c|}{$\mathrm{LB}(4)=0.3454 ; \mathrm{LB}(8)=0.7391$} & \multicolumn{2}{|c|}{$\mathrm{LB}(4)=0.0523 ; \mathrm{LB}(8)=0.2944$} \\
\hline \multicolumn{3}{|c|}{$\mathrm{LB}(12)=0.5060$} & \multicolumn{2}{|c|}{$\mathrm{LB}(12)=0.3988$} \\
\hline
\end{tabular}

$z_{t-1}$ : residuals of the long-term relationship between LREER (or LRER) and LOIL in t-1. LCH stands for LREER or LRER alternatively. Between brackets: t-statistics of estimated coefficients. $\mathrm{LB}(\mathrm{k})$ is the p-value of the Ljung-Box test of no autocorrelation for $\mathrm{k}$ lags.

The results of the causality tests are reported in Table 7. Concerning the effective exchange rate, the results obtained from a VAR(1) model in level exhibit a causality from the oil price to the exchange rate at the $5 \%$ significance level. For the bilateral exchange rate, 
China and the Relationship between the Oil Price and the Dollar

Table 7: Results of causality tests (p-values)

\begin{tabular}{lcccccccc}
\hline & VAR(1) & VAR(2) & VAR(3) & VAR(4) & VAR(6) & VAR(8) & VAR(10) & VAR(12) \\
\hline \multicolumn{7}{c}{ Real effective exchange rate } \\
\hline $\mathrm{O} \rightarrow \mathrm{C}$ & $0.032^{* *}$ & 0.136 & 0.156 & 0.160 & 0.286 & 0.366 & 0.500 & 0.263 \\
$\mathrm{C} \rightarrow \mathrm{O}$ & 0.596 & 0.608 & 0.521 & 0.625 & 0.476 & 0.764 & 0.828 & 0.836 \\
\hline \multicolumn{7}{c}{ Real bilateral exchange rate } \\
\hline $\mathrm{O} \rightarrow \mathrm{C}$ & 0.195 & 0.258 & 0.197 & 0.195 & 0.120 & $0.086^{*}$ & 0.117 & $0.047^{* *}$ \\
\hline $\mathrm{C} \rightarrow \mathrm{O}$ & 0.513 & 0.244 & 0.207 & 0.235 & 0.340 & 0.295 & 0.437 & 0.350 \\
\hline $\mathrm{O} \rightarrow \mathrm{C}$ is for the null hypothesis of no causality from oil prices to the exchange rate. \\
$\mathrm{C} \rightarrow \mathrm{O}$ is for the null hypothesis of no causality from the exchange rate to oil prices. \\
$* *$ (resp. ${ }^{*}$ ): rejection of the null hypothesis at the 5\% (resp. 10\%) significance level.
\end{tabular}

such a causality appears for high lags (8 and 12 lags). Like in the previous section, the null hypothesis of no causality from the exchange rate to the oil price is never rejected, for any lags in the VAR model estimation. Hence, the results for the 1980-2004 sub-period are consistent with those obtained for the whole period. On the whole, our results are consistent with previous studies (Chaudhuri and Daniel (1998), for instance). Then, the 2002-2004 pattern appears atypical in that the dollar depreciated when the oil price was rising. Cointegration analysis, which relies on long-run series, is unable to tell whether the 2002-2004 period could be the beginning of a new regime. In the next section, we try to investigate this possibility through the use of a theoretical framework.

\section{Oil and dollar: what is new with China?}

\subsection{The model}

The model proposed here aims at studying whether the emergence of China as a major player on both oil and foreign exchange markets could theoretically change the nature of the link between the price of oil and the price of the dollar. It is a four-country extension of Krugman (1980). The four considered countries are Europe (noted E) ${ }^{13}$, the United States $(\mathrm{U})$, OPEC $(\mathrm{O})$ and China (C). Europe, the United States and China import oil from OPEC and sell goods to other countries. OPEC sells oil and imports goods. The goods from Europe, the United States and China are imperfect substitutes. There is only one exchange rate in the model: the dollar against the euro, since China and OPEC are assumed to peg their currencies to the dollar. The price index of Chinese goods is assumed to follow the US

\footnotetext{
${ }^{13}$ Europe could be extended to any industrialized oil-importing country with a flexible exchange rate against the dollar, i.e. Japan for example. In the same way, China could be extended to any emerging oil-importing country with a fixed exchange rate against the dollar.
} 
one, i.e. there is no Balassa-Samuelson effect in the model ${ }^{14}$ This allows us to identify the bilateral real exchange rate of the yuan against the euro to the bilateral rate between the US dollar and the euro. This rate is noted Q hereafter. A rise in Q denotes an appreciation of the dollar, hence a depreciation of the euro in real terms. The trade accounts $B_{i}(i=\mathrm{E}, \mathrm{U}, \mathrm{C}, \mathrm{O})$ are expressed in real dollars (i.e. in units of US goods):

Europe:

$$
B_{E}=T_{E U}(Q)+T_{E C}(Q)+\gamma_{E}(Q) X-P_{O} O_{E}
$$

where $T_{E U}$ and $T_{E C}$ stand for the bilateral trade account of Europe vis-à-vis the United States and China respectively $\left(T_{E U}^{\prime}>0, T_{E C}^{\prime}>0\right), X$ is the total volume of OPEC imports, $\gamma_{E}$ the share of Europe in OPEC imports $\left(\gamma_{E}^{\prime}>0\right), O_{E}$ is the exogenous volume of European oil imports, and $P_{O}$ the exogenous real price of oil (i.e. the ratio of oil price to US GDP deflator) ${ }^{15}$

United States:

$$
B_{U}=-T_{E U}(Q)+T_{U C}+\gamma_{U}(Q) X-P_{O} O_{U}
$$

where $T_{U C}$ denotes the exogenous bilateral trade account of the United States against China (remember that the bilateral exchange rate between the two countries is fixed), $\gamma_{U}$ is the share of the United States in OPEC imports $\left(\gamma_{U}^{\prime}<0\right)$ and $O_{U}$ is the exogenous volume of US oil imports.

China:

$$
B_{C}=-T_{E C}(Q)-T_{U C}+\gamma_{C}(Q) X-P_{O} O_{C}
$$

Like for the two other countries, $O_{C}$ denotes the volume of Chinese oil imports and $\gamma_{C}$ the share of China in OPEC imports. Since we have $\gamma_{C}=1-\gamma_{E}-\gamma_{U}$, the sign of $\gamma_{C}^{\prime}$ is theoretically ambiguous. We assume $\gamma_{E}^{\prime}$ to be larger than $\gamma_{U}^{\prime}$ in absolute value (because a euro depreciation raises European competitiveness against both the United States and China, whereas it reduces US competitiveness only compared to Europe), hence $\gamma_{C}^{\prime}<0$.

OPEC:

$$
B_{O}=P_{O} O-X
$$

with $O=O_{E}+O_{U}+O_{C}$. OPEC imports $X$ are assumed to adjust gradually to export receipts:

$$
\frac{d X}{X}=\lambda\left(P_{O} O-X\right), 0<\lambda<1
$$

Summing up Equations (1) to (4), we get $B_{E}+B_{U}+B_{C}+B_{O}=0$. Hence trade balances are consistent and no rest of the world is needed to close the model.

\footnotetext{
${ }^{14}$ From 1980 to 2004, the Chinese CPI has not grown faster than the US one on average. The lack of Balassa-Samuelson effect in China is documented by Coudert and Couharde (2005).

${ }^{15}$ The exogeneity of $P_{O}$ is relaxed in the last subsection.
} 
There are only two assets in the model: dollar-denominated assets noted $D$, and eurodenominated assets noted $E$. The behavior of European asset holders consists in keeping constant the euro value (in real terms) of their holdings in dollars, hence they buy dollars when the dollar depreciates and sell dollars when it appreciates, whatever their current account: $Q D_{E}=$ cst, hence

$$
\frac{d D_{E}}{D_{E}}=-\frac{d Q}{Q}
$$

where $D_{E}$ denotes European holdings of dollar-denominated assets. Similarly, US asset holders are assumed to keep constant the dollar value (in real terms) of their eurodenominated assets: $E_{U} / Q=c s t$, hence

$$
\frac{d E_{U}}{E_{U}}=\frac{d Q}{Q}
$$

This specification means that current account imbalances of the two industrialized countries will have to be met by capital flows from OPEC and China. The latter countries are assumed to allocate their net foreign asset (NFA) position ( $W_{O}$ and $W_{C}$, respectively) in fixed proportions in euros and in dollars. We denote $\alpha_{O}$ and $\alpha_{C}$ the share of the euro in OPEC and Chinese holdings, respectively. $W_{O}$ and $W_{C}$ being expressed in real dollars, their variation is equal to the trade balance plus valuation effects on euro-denominated assets:

$$
\begin{aligned}
& d W_{O}=B_{O}-\alpha_{O} W_{O} \frac{d Q}{Q} \\
& d W_{C}=B_{C}-\alpha_{C} W_{C} \frac{d Q}{Q}
\end{aligned}
$$

Keeping constant the proportion of euro-denominated assets means that:

$$
\frac{E_{O} / Q}{W_{O}}=\alpha_{O}=c s t
$$

and

$$
\frac{E_{C} / Q}{W_{C}}=\alpha_{C}=c s t
$$

Therefore, the net demand of OPEC for euro-denominated assets can be expressed in dollars as:

$$
\frac{d E_{O}}{Q}=\frac{\alpha_{O}}{Q}\left(Q d W_{O}+W_{O} d Q\right)=\alpha_{O} d W_{O}+\alpha_{O} W_{O} \frac{d Q}{Q}
$$


In the same way, we have:

$$
\frac{d E_{C}}{Q}=\frac{\alpha_{C}}{Q}\left(Q d W_{C}+W_{C} d Q\right)=\alpha_{C} d W_{C}+\alpha_{C} W_{C} \frac{d Q}{Q}
$$

On the whole, net foreign capital inflows in Europe can be written in dollars as:

$$
K_{E}=\frac{d E_{U}}{Q}+\frac{d E_{O}}{Q}+\frac{d E_{C}}{Q}-d D_{E}
$$

Replacing each term by its value yields:

$$
K_{E}=\left(\frac{E_{U}}{Q}+D_{E}+\alpha_{O}\left(1-\alpha_{O}\right) W_{O}+\alpha_{C}\left(1-\alpha_{C}\right) W_{C}\right) \frac{d Q}{Q}+\alpha_{O} B_{O}+\alpha_{C} B_{C}
$$

The balance of payment equilibrium for Europe implies that $B_{E}+K_{E}=0$, which leads to:

$$
\frac{d Q}{Q}=-\frac{B_{E}+\alpha_{O} B_{O}+\alpha_{C} B_{C}}{\frac{E_{U}}{Q}+D_{E}+\alpha_{O}\left(1-\alpha_{O}\right) W_{O}+\alpha_{C}\left(1-\alpha_{C}\right) W_{C}}
$$

As the denominator of (16) is positive, a rise in $B_{E}, B_{O}$ or $B_{C}$ is associated to a dollar depreciation (fall in $Q$ ). However (16) is not a reduced form since $B_{E}$ and $B_{C}$ do react to the euro/dollar exchange rate.

\subsection{The impact of the oil price on the euro/dollar exchange rate}

Due to the savings behavior of OPEC (Equation (5)), the impact of an oil price variation is different in the short run and in the long run.

In the short run, $W_{O}$ and $W_{C}$ are predetermined. $X$ is also constant, hence an oil price hike leads to a one-for-one increase in OPEC savings. Since the real exchange rate cannot jump on impact (because there are no expectations in the model), $Q$ is predetermined and its rate of variation follows:

$$
\frac{\partial(d Q / Q)}{\partial\left(P_{O}\right)}=\frac{\sigma_{E}+\alpha_{C} \sigma_{C}-\alpha_{O}}{\frac{E_{U}}{Q}+D_{E}+\alpha_{O}\left(1-\alpha_{O}\right) W_{O}+\alpha_{C}\left(1-\alpha_{C}\right) W_{C}} O
$$

where $\sigma_{E}$ and $\sigma_{C}$ represent the shares of Europe and China respectively in OPEC oil exports $\left(\sigma_{E}=O_{E} / O\right.$ and $\sigma_{C}=O_{C} / O$ ). From Equation (17) it can be concluded that an oil price increase leads to a depreciation of the euro against the dollar (rise in $Q$ ) in the short run if: 


$$
\alpha_{O}-\alpha_{C} \sigma_{C}<\sigma_{E}
$$

The left hand-side of (18) represents the net variation in the international demand for euros following a rise in the oil price: the demand by OPEC rises by $\alpha_{O}$ whereas the demand by China falls by $\alpha_{C} \sigma_{C}{ }^{16}$ The right hand-side of $(18)$ represents the additional needs for foreign capital in Europe (fall in the trade balance). Hence this inequality states that the euro will depreciate if the additional demand for euros does not meet the additional needs from Europe.

In Krugman (1980), there are only three countries, hence $\alpha_{C}=\sigma_{C}=0$ and condition (18) reduces to $\alpha_{O}<\sigma_{E}$ : the euro depreciates following an oil price increase if the rise in OPEC demand for euros is not enough to meet the deterioration of the European trade balance. Here we see that condition (18) is easier to meet with the presence of China as soon as the Chinese portfolio is not $100 \%$ in dollars $\left(\alpha_{C}>0\right)$. This is because the fall in Chinese trade balance following an oil price hike reduces the demand for euros. In practice, however, this effect is unlikely to be large. Indeed, official reserves have been little diversified despite repeated communication by the People's Bank of China concerning further diversification into euros, and private investment abroad has not been liberalized.

In the long run, $W_{O}$ and $W_{C}$ are endogenous. In addition, we have $X=P_{O} O$, hence an oil price hike leads to a one-for-one rise in OPEC imports and $B_{O}=0$. The stabilization of the real exchange rate implies that $d Q / Q=0$. Hence, $B_{E}+K_{E}=0$ leads to:

$$
B_{E}+\alpha_{C} B_{C}=0
$$

Deriving the trade accounts by $P_{O}$ and $Q$ leads to (see Appendix):

$$
\frac{\partial Q}{\partial P_{O}}=\frac{\alpha_{C}\left(\sigma_{C}-\gamma_{C}\right)+\left(\sigma_{E}-\gamma_{E}\right)}{T_{E U}^{\prime}+\left(1-\alpha_{C}\right) T_{E C}^{\prime}+P_{O} O\left(\alpha_{C} \gamma_{C}^{\prime}+\gamma_{E}^{\prime}\right)} O
$$

Here, we assume that $\alpha_{C} \gamma_{C}^{\prime}+\gamma_{E}^{\prime}>0$, meaning that a depreciation of the euro has a positive impact on the European balance of payments: the rise in OPEC demand for European products $\left(\gamma_{E}^{\prime}>0\right)$ dominates the fall in Chinese demand for euro-denominated assets $\left(\alpha_{C} \gamma_{C}^{\prime}\right)$. Hence the denominator of 20 is positive and a rise in the oil price leads the euro to depreciate against the dollar if:

$$
\alpha_{C}\left(\gamma_{C}-\sigma_{C}\right)<\sigma_{E}-\gamma_{E}
$$

\footnotetext{
${ }^{16}$ The demand by the United States does not move because the exchange rate is not (yet) affected.
} 
The left hand-side of (21) represents the net impact of the oil price hike on Chinese demand for euros in the long run: Chinese trade account rises if the share of China as a supplier of OPEC $\left(\gamma_{C}\right)$ exceeds the share of China as an oil importer $\left(\sigma_{C}\right)$; the proportion of the trade balance variation which is invested in euros is $\alpha_{C}$. The right hand-side represents the net effect of the oil-price increase on European trade deficit, hence on the needs for foreign investment in Europe. The euro depreciates in the long run if the Chinese additional demand for euros is lower than the deterioration of the European trade account.

In a three country model (i.e. without China), the left hand-side of 21] is zero, hence the condition reduces to $\gamma_{E}<\sigma_{E}$ : the euro depreciates in the long run after an oil price increase if the European trade balance deteriorates. According to Figures 3 and 4 , however, the share of the Eurozone as a supplier of OPEC (26\% in 2003) is close to the share of the Eurozone in world oil demand (25.5\% in 2003). Hence, without China, the euro/dollar exchange rate is expected to come back to baseline in the long run after an oil price variation. In this respect, the positive cointegration relationship between the oil price and the dollar found in Section 2 would stem from OPEC not consuming all its export receipts over the estimation period, reflecting a medium-run equilibrium in-between the short run and the long run of the theoretical model.

Now add China. According to Figures 3 and 4 , in 2003, the market share of China in OPEC was $6.8 \%$ (approximatively the same as those of the United States and Japan) whereas its share in world oil imports was only $4.2 \%$, meaning that we have $\gamma_{C}>\sigma_{C}$ : the Chinese trade account rises in the long term following an oil-price hike. This leads the Chinese demand for euros to increase in the long term, provided $\alpha_{C}$ is not too low. Hence, accounting for China in 21] creates the possibility that the euro appreciates in the long run following an oil price hike. As long as $\alpha_{C}$ remains small, this possibility is muted. However, a diversification of Chinese foreign exchange reserves could raise the case of a positive causality from the oil price to the euro exchange rate in the long run, or at least reduce the case for a negative relation.

On the whole, the presence of China could possibly reinforce the depreciation of the euro in the short run following a rise in the oil price. By contrast, in the long run, provided there is some diversification of Chinese official reserves, an oil price increase could lead to an appreciation of the euro. But these two effects are unable to explain the observed depreciation of the dollar in 2002-2004 while the oil price was rising. We now turn to the reverse impact of the exchange rate on the oil price.

\subsection{The impact of the euro/dollar exchange rate on the oil price}

The Granger causality tests presented in Section 2 suggest that the exchange rate does not cause the oil price. However the atypical negative correlation between the prices of oil and of the dollar observed in 2002-2004 could stem from a new regime where the causality 
Figure 3: Country breakdown of world oil imports in \% (crude oil)

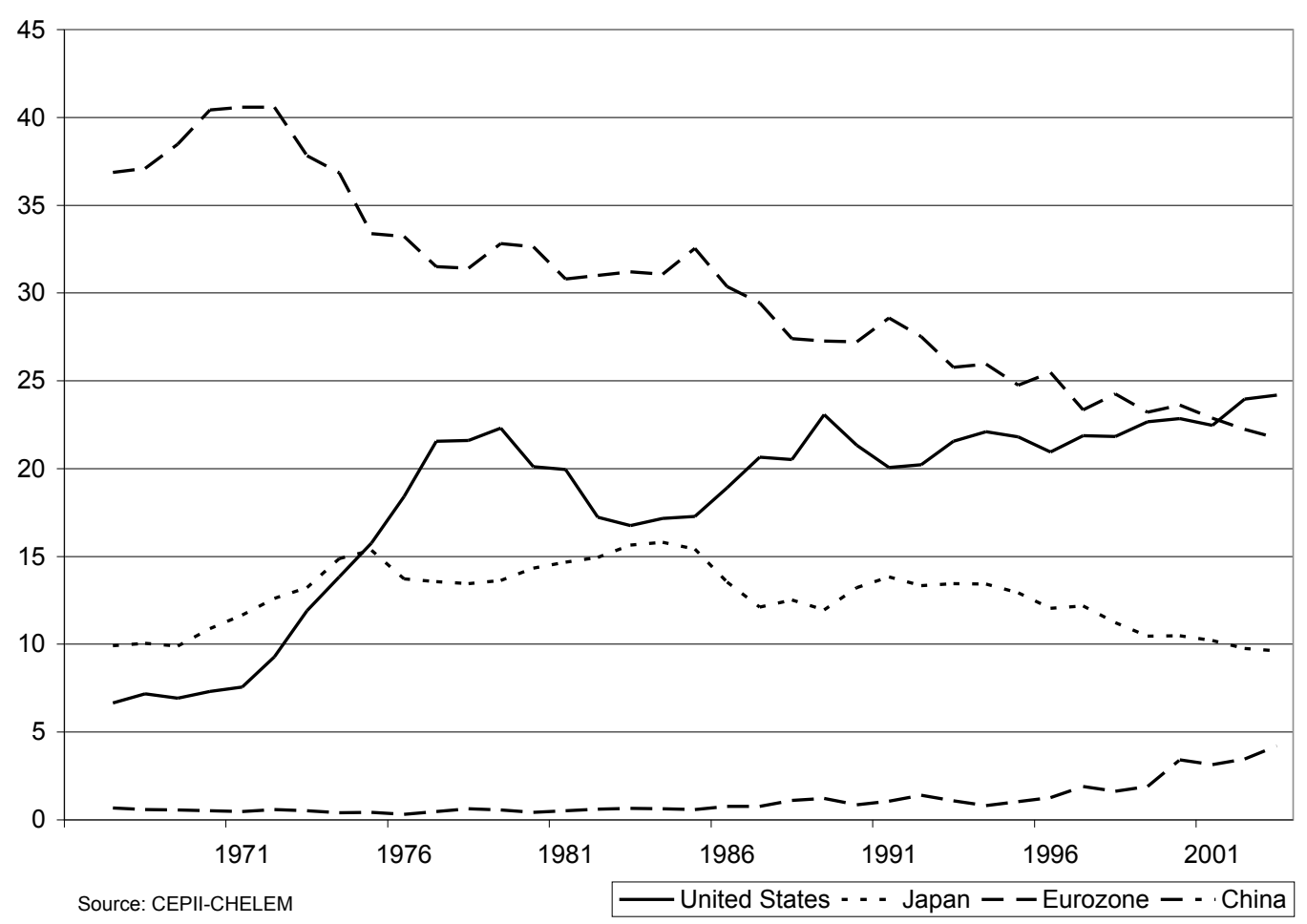

would run the other way. Here we investigate this possibility theoretically ${ }^{17}$ To this aim, we have to relax the assumption of an exogenous demand for oil and alternatively assume that oil demand is a negative function of the oil price (with the same price elasticity $\epsilon>0$ in the three importing countries). It is also a function of activity, hence of aggregate demand for goods and services $Y_{i}(i=E, U, C): 18$

$$
\begin{aligned}
O_{E} & =P_{O}^{-\epsilon} \omega_{E} Y_{E}(Q), \quad Y_{E}^{\prime}>0 \\
O_{U} & =P_{O}^{-\epsilon} \omega_{U} Y_{U}(Q), \quad Y_{U}^{\prime}<0 \\
O_{C}=P_{O}^{-\epsilon} \omega_{C} Y_{C}(Q), & Y_{C}^{\prime}<0
\end{aligned}
$$

\footnotetext{
${ }^{17}$ We cannot test it econometrically due to data shortage.

${ }^{18}$ Aggregate demands are expressed in terms of US goods.
} 
Figure 4: Country breakdown of OPEC imports in \%

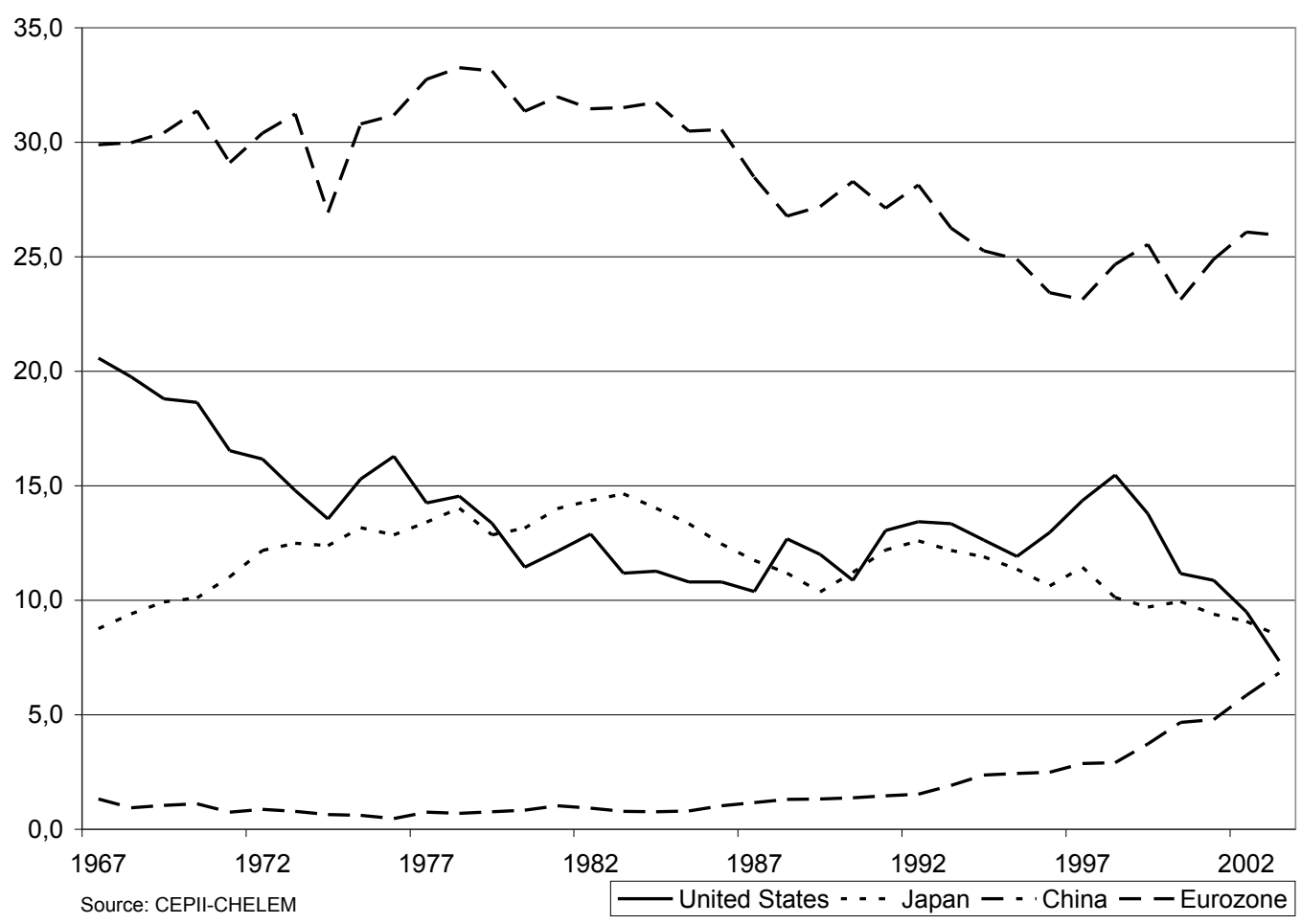

The $\omega_{i} \mathrm{~s}(i=E, U, C)$ are technical parameters reflecting the energy-intensity of each economy. The $Y_{i}$ s represent aggregate demand in each country as a function of the real exchange rate. The closure of international trade would imply $Y_{E}^{\prime}+Y_{U}^{\prime}+Y_{C}^{\prime}=0$. However, the impact of the euro/dollar exchange rate on Chinese aggregate demand $Y_{C}$ also goes through the Chinese monetary mechanism. Indeed, to the extent that official interventions are not fully sterilized, a depreciation of the dollar against the euro translates into monetary growth that boosts Chinese activity ${ }^{19}$ Therefore, $Y_{C}^{\prime}$ is likely to be especially high in absolute value, leading to $Y_{E}^{\prime}+Y_{U}^{\prime}+Y_{C}^{\prime}<0$.

Oil supply $O$ is still assumed to be exogenous ${ }^{20}$ The oil market clearance condition leads to:

\footnotetext{
${ }^{19}$ In the long run, monetary growth should fuel a price increase, with no real effect. However, partly due to the peculiarities of the Chinese labor market, such inflation has not shown up in the data so far. It has had more impact on asset prices.

${ }^{20}$ Alternatively, oil supply could be assumed a positive function of the oil price, without chang-
} 


$$
O=P_{O}^{-\epsilon}\left(\omega_{E} Y_{E}(Q)+\omega_{U} Y_{U}(Q)+\omega_{C} Y_{C}(Q)\right)
$$

Hence :

$$
P_{O}=\left(\frac{\omega_{E} Y_{E}(Q)+\omega_{U} Y_{U}(Q)+\omega_{C} Y_{C}(Q)}{O}\right)^{1 / \epsilon}
$$

The impact of the euro/dollar exchange rate on the oil price then comes as:

$$
\frac{\partial P_{O}}{\partial Q}=\frac{1}{\epsilon O}\left(\omega_{E} Y_{E}^{\prime}+\omega_{U} Y_{U}^{\prime}+\omega_{C} Y_{C}^{\prime}\right)\left(\frac{\omega_{E} Y_{E}(Q)+\omega_{U} Y_{U}(Q)+\omega_{C} Y_{C}(Q)}{O}\right)^{\frac{1}{\epsilon}-1}
$$

According to (27), a real depreciation of the dollar (fall in $Q$ ) leads to a rise in the oil price if:

$$
\omega_{E} Y_{E}^{\prime}<-\left(\omega_{U} Y_{U}^{\prime}+\omega_{C} Y_{C}^{\prime}\right)
$$

Both sides of (28) are positive. It follows that the oil price rises following a dollar depreciation if the demand for oil by the "dollar bloc" is more sensitive than that by the Eurozone. This can come either from higher sensitiveness of output to the real exchange rate or from more energy-intensive production function. In a three-country model (i.e. without China), (28) reduces to $\omega_{E} Y_{E}^{\prime}<-\omega_{U} Y_{U}^{\prime}$. $\omega_{E}$ is smaller than $\omega_{U}$ but $Y_{U}^{\prime}$ is likely to be smaller than $Y_{E}^{\prime}$ in absolute value (because many countries have a fixed exchange rate de jure or de facto against the dollar). Therefore, the sign of $\omega_{E} Y_{E}^{\prime}+\omega_{U} Y_{U}^{\prime}$ is ambiguous, which fits the absence of causality from the dollar to the oil price over the past.

Now add China. According to IEA statistics (IEA, 2005a,b), the Chinese oil intensity of output is more than twice the US one, the latter being above the European one. Of course, these differences are highly influenced by the way output is valued, i.e. on the exchange rate used: because the yuan is undervalued compared to its purchasing power parity level, Chinese GDP is undervalued when converted into US dollars with current exchange rates,

ing the results qualitatively. It could also be argued that OPEC quotas depend on the euro/dollar exchange rate because OPEC targets the purchasing power of each unit of exports: a depreciation of the dollar would then induce OPEC to raise quotas in order to stabilize the purchasing power of oil exports receipts in terms of imported goods from Europe. Alternatively, OPEC may choose to reduce quotas in case of a dollar depreciation in order to compensate the shock by an oil price increase (see Yousefi and Wirjanto, 2003). On the whole, the impact of the euro/dollar exchange rate on oil supply is ambiguous and we prefer to neglect it here. 
which raises oil intensity; when using a PPP exchange rate, Chinese intensity shows up very low (see Figure 5). In our model, however, the technical coefficients $\omega_{i}$ apply to outputs $Y_{i}$ which are expressed in real dollars at current real exchange rate $Q{ }^{21}$ This suggests that $\omega_{C}$ is likely to be much larger than $\omega_{U}$ itself larger than $\omega_{E}$. In addition, due to its specialization in low-quality products and to its exchange-rate mechanism that makes the real money stock rise when the dollar depreciates, China is likely to display a high sensitivity of aggregate demand to the euro/dollar exchange rate, which means that $Y_{C}^{\prime}$ is high in absolute value. On the whole, there are increasing reasons for Condition (28) to be met, i.e. for a dollar depreciation to be followed by a rise in oil price.

Figure 5: Oil intensities on 2003 (oil supply in tonnes of oil equivalent/GDP in dollars, using two alternative exchange rates)

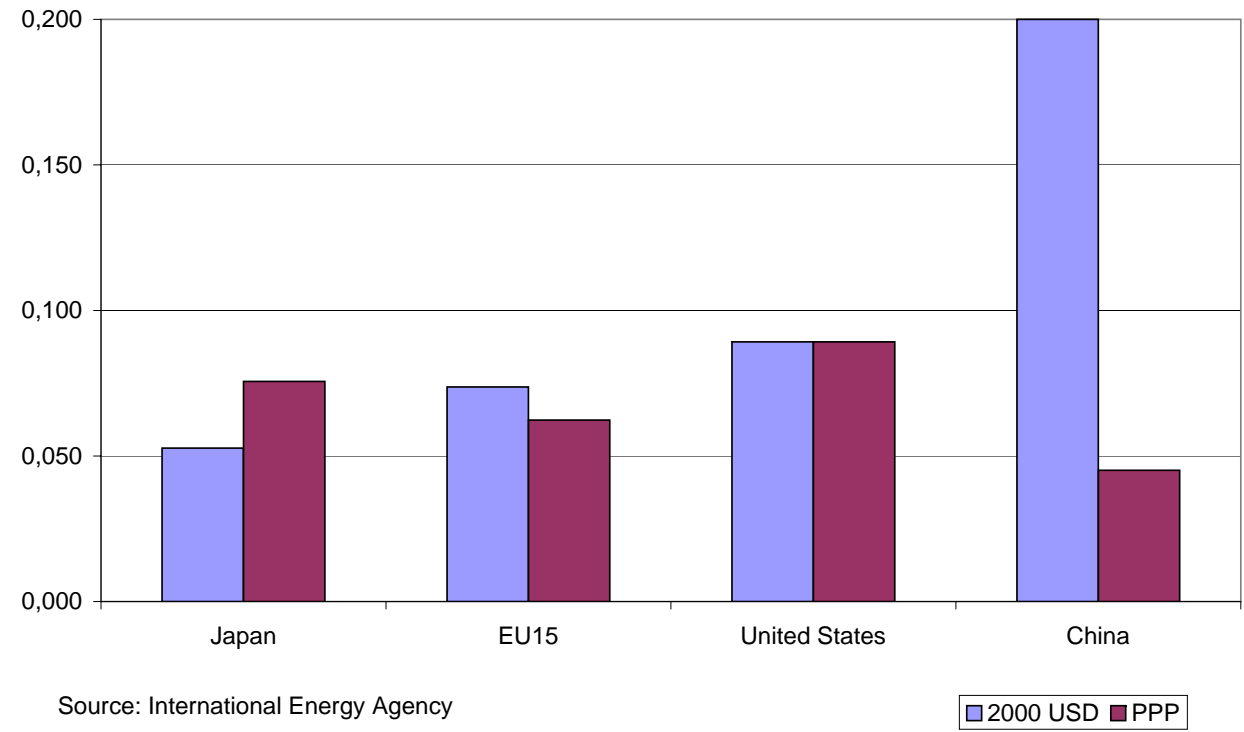

\footnotetext{
${ }^{21}$ This is consistent with oil demands which are also expressed in current real dollars
} 


\section{Conclusion}

In this paper, we have tried to revisit the relationship between the price of oil and the dollar effective exchange rate. First, we have shown evidence of a long-term relation (i.e. a cointegration relation) between the two series in real terms, and of a causality running from oil to the dollar, over the 1974-2004 period. Our estimates suggest that, other things equal, a $10 \%$ rise in the oil price leads to a $4.3 \%$ appreciation of the dollar in real effective terms in the long run. The estimation of a vector error correction model shows a slow adjustment speed of the dollar real effective exchange rate to the long-term target (with a half-life of deviations of about $61 / 2$ years). Although consistent with previous studies, our empirical results are unable to explain the evolutions observed in 2002-2004, with a rise in oil prices while the dollar was depreciating. In a second step, we study whether the 2002-2004 period could be the beginning of a new regime with negative correlation between the dollar and the oil price. Our analysis is based on an extension of Krugman (1980) to the case of four countries (the United States, the Eurozone, OPEC and China) and only one exchange rate (the dollar against the euro). We find that the emergence of China in both oil and foreign exchange markets could strengthen the positive causality found from the oil price to the dollar in the short run but reverse its sign in the long run. In addition, the emergence of China, with energy-intensive growth driven by ballooning exports and a fixed exchange rate against the dollar, could give rise to a negative reverse causality from the dollar to the oil price. The intuition is that a dollar depreciation has a positive impact on Chinese economic activity due to the fixed peg of the yuan against the dollar; this entails increased demand for oil, hence a rise in its real price.

In July 2005, the Chinese exchange-rate regime was officially moved to a managed float referring to a basket of foreign currencies. However the composition of the basket was not revealed and the yuan has de facto stayed pegged on the US dollar. The paper argues that such status quo could strengthen the pattern observed in 2002-2004 of a rising oil price with a depreciating dollar. Conversely, should the Chinese regime effectively move to a managed float or basket peg, such relationship could be weakened or even reversed back to the traditional, positive relationship between the oil price and dollar. This analysis has strong policy implications for the Eurozone since a negative relationship between the oil price and the dollar tends to stabilize the oil bill of the zone. 


\section{References}

Amano, R., And S. VAn Norden (1998), "Oil Prices and the Rise and Fall of the US Real Exchange rate", Journal of International Money and Finance, 17 (2), pp. 299-316.

Chaudhuri, K., And B.C. Daniel (1998), "Long-run Equilibrium Real Exchange Rates and Oil Prices”, Economics Letters, 58 (2), pp. 231-238.

Coudert, V. And C. Couharde (2005), "Real Equilibrium Exchange Rate in China", CEPII working paper 2005-01.

Dibooglu, S. (1996), "Real Disturbances, Relative Prices, and Purchasing Power Parity”, Journal of Macroeconomics, 18 (1), pp. 69-87.

Engle, R., Hendry, D. And J. Richard (1983), "Exogeneity", Econometrica, 51, pp. 277-304.

Golub, S. (1983), "Oil Prices and Exchange Rates", The Economic Journal, 93, pp. 576-593.

InTERnATIONAL ENERgy AGENCy (2005a), Energy Balances for Non-OECD Members, OECD/IEA, Paris, 363 p.

International Energy Agency (2005b), Energy Balances for OECD Members, OECD/IEA, Paris, 351 p.

International Monetary Fund (2005a), "Will the Oil Market Continue to Be Tight?", World Economic Outlook, chapter 4, pp. 157-183, April.

InTERnational MONETARy Fund (2005b), International Financial Statistics.

Johansen, S. (1988), "Statistical Analysis of Cointegration Vectors", Journal of Economic Dynamics and Control, 12, pp. 231-254.

JoHANSEN, S. AND K. Juselius (1990), "Maximum Likelihood Estimation and Inference on Cointegration with Application to the Demand for Money", Oxford Bulletin of Economics and Statistics, 52, pp. 169-210.

Krugman, P. (1980), “Oil and the Dollar”, NBER working paper 554.

OECD (2004), "Oil Price Developments: Drivers, Economic Consequences and Policy Responses", OECD Economic Outlook, 76, December.

OPEC (2004), “Oil Outlook to 2025”, OPEC Review paper, www.opec.org/library/. 
Rogoff, K. (1996), "The Purchasing Power Parity Puzzle", Journal of Economic Literature, 34 , pp. 647-668.

Throop, A. (1993), "A Generalized Uncovered Interest Parity Model of Exchange Rates", Federal Reserve of San Francisco Economic Review, 2, pp. 3-16.

Yousefi, A. And T.S. WiRJanto (2003), "The Empirical Role of the Exchange Rate on the Crude-Oil Price Formation", Energy Economics, 26, pp. 783-799.

World BANK (2005), Global Development Finance 2005, Washington DC, 106 p.

ZHOU, S. (1995), "The Response of Real Exchange Rates to Various Economic Shocks", Southern Journal of Economics, pp. 936-954. 


\section{Appendix}

\section{A Unit root tests}

Table A1: Unit root tests (whole period)

\begin{tabular}{|c|c|c|c|c|}
\hline & \multicolumn{2}{|c|}{$\begin{array}{l}\text { US effective } \\
\text { exchange rate }\end{array}$} & \multicolumn{2}{|c|}{ Oil price } \\
\hline & LREER & $\triangle$ LREER & LOIL & $\Delta \mathrm{LOIL}$ \\
\hline ADF test & $-0.30(1)$ & $-14.55 *(1)$ & 0.07 (1) & $-15.89 *(1)$ \\
\hline PP test & $-0.29(1)$ & $-14.36^{*}(1)$ & 0.12 (1) & $-15.68 *(1)$ \\
\hline
\end{tabular}

(1) model without constant nor trend.

Table A2: Unit root tests (Period 1980.01-2004.11)

\begin{tabular}{ccccccc}
\hline & \multicolumn{3}{c}{ US effective } & \multicolumn{2}{c}{ US bilateral } & \multicolumn{2}{c}{$\begin{array}{c}\text { Oil price } \\
\text { exchange rate (LREER) }\end{array}$} & exchange rate (LRER) & \multicolumn{2}{c}{ (LOIL) } \\
\hline Level & $\Delta$ & Level & $\Delta$ & Level & $\Delta$ \\
ADF test & $-0.06(1)$ & $-12.93^{*}(1)$ & $-1.21(1)$ & $-12.37 *(1)$ & $-0.72(1)$ & $-12.95^{*}(1)$ \\
PP test & $-0.04(1)$ & $-12.74 *(1)$ & $-1.36(1)$ & $-12.37 *(1)$ & $-0.82(1)$ & $-12.44^{*}(1)$ \\
\hline \multicolumn{3}{c}{$*$ rejection of the null hypothesis of a unit root at the 5\% significance level. }
\end{tabular}

(1) model without constant nor trend.

\section{B The long-term impact of the oil price on the dollar}

In the long run, we have $d Q / Q=0$ but we also have $X=P_{O} O$ and $B_{O}=0$. [19, on page 21 states that:

$$
\alpha_{C} B_{C}+B_{E}=0
$$

The partial derivatives of (1) and (3) relative to $P_{O}$ yield:

$$
\begin{aligned}
& \frac{\partial B_{E}}{\partial P_{O}}=\left(T_{E U}^{\prime}+T_{E C}^{\prime}+\gamma_{E}^{\prime} X\right) \frac{\partial Q}{\partial P_{O}}+\left(\gamma_{E}-\sigma_{E}\right) O \\
& \frac{\partial B_{C}}{\partial P_{O}}=\left(-T_{E C}^{\prime}+\gamma_{C}^{\prime} X\right) \frac{\partial Q}{\partial P_{O}}+\left(\gamma_{C}-\sigma_{C}\right) O
\end{aligned}
$$


Incorporating $\mathrm{B} 2$ and $\mathrm{B} 3 \mathrm{into} \mathrm{B} 1 \mathrm{a}$ and rearranging for $\frac{\partial Q}{\partial P_{O}}$ leads to:

$$
\frac{\partial Q}{\partial P_{O}}=\frac{\alpha_{C}\left(\sigma_{C}-\gamma_{C}\right)+\left(\sigma_{E}-\gamma_{E}\right)}{T_{E U}^{\prime}+T_{E C}^{\prime}+\gamma_{E}^{\prime} X-\alpha_{C} T_{E C}^{\prime}+\alpha_{C} \gamma_{C}^{\prime} X}
$$

Rearranging the denominator of (B4) and remembering that $X=P_{O} O$ lead to 20). 